\title{
18. ELEMENTAL ABUNDANCE PATTERNS IN LEG 34 ROCKS
}

\author{
John B. Corliss, Jack Dymond, and Carlos Lopez, \\ School of Oceanography, Oregon State University, Corvallis, Oregon
}

\section{ANALYTICAL PROCEDURES}

Data were obtained by instrumental neutron activation analysis (INAA) and atomic absorption spectrometry (AAS) for major and trace elements. Water was determined on a DuPont water analyzer. The sample positions in the cores are indicated in Figure 1 and the sample numbers are listed in Table 1. The abundance data are listed by increasing depth in each hole in Tables 2A-D.

\section{ANALYSIS OF DATA}

Figures 2 through 6 are scatter plots of some of the elemental abundance data and Figure 7 is a plot of potassium versus total water. Several general observations regarding the elemental distribution patterns can be derived from these:

1) The rocks can be divided into coherent chemical groups on the basis of their elemental abundances. These include the upper part of the basalt section at Holes 319 and 319A (Samples 319-1, 319-2, 319A-1), the lower part of Hole 319A (Samples 319A-2 through 319A-19), and the rocks from Site 321.

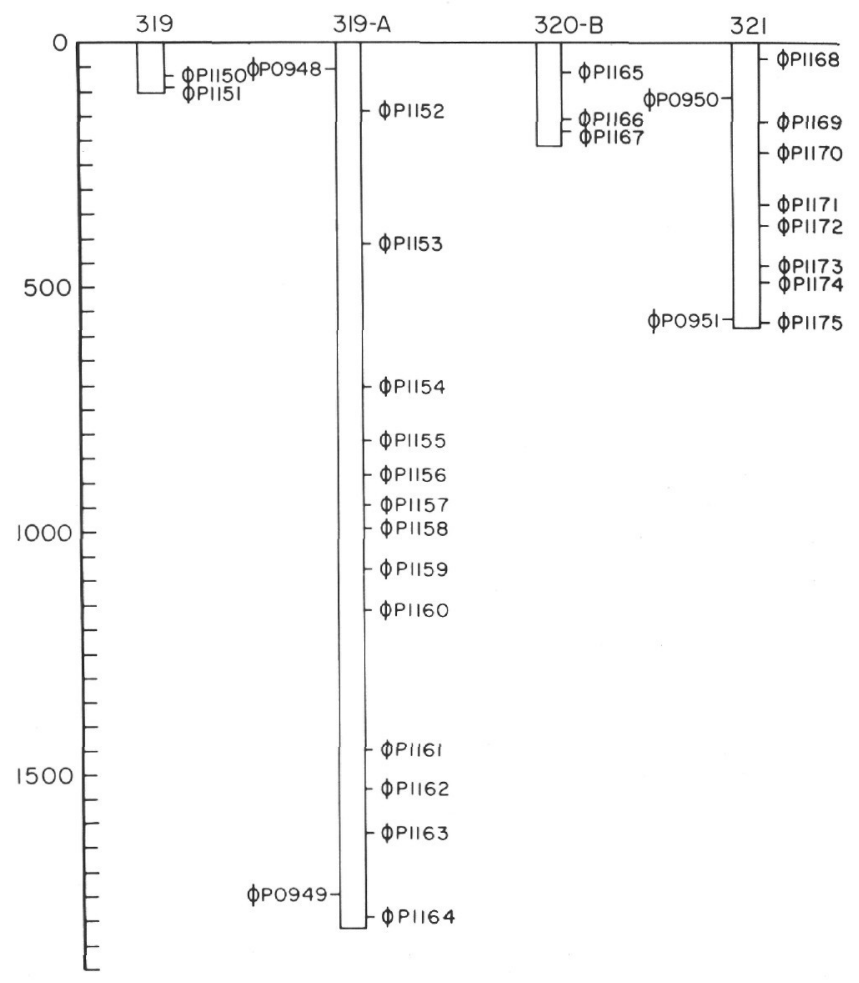

Figure 1. Positions of samples.
2) Many element pairs are strongly covariant, but for most of these the covariance results primarily from site to site variation rather than variations within the rocks from a single site. Some exceptions can be seen, most notably $\mathrm{Fe}$ and $\mathrm{Ni}$ in Hole 319 rocks.

3) Several samples have anomalous potassium contents (Figure 7), presumably due to the addition of seawater during alteration. An example of this effect can be seen in a pair of samples from the same piece of rock, Samples 319A-7 and 319A-8. Sample 7, with 0.16\% K and $1.45 \%$ total $\mathrm{H}_{2} \mathrm{O}$ is fresh, while Sample 8 from an altered portion of the rock has $0.42 \% \mathrm{~K}$ and $2.04 \%$ total $\mathrm{H}_{2} \mathrm{O}$. Some of these altered samples have anomalous abundances of other elements and have been deleted from the scatter plots and calculations of means.

Figure 8 is a normalization plot of the mean abundances of each of the clustered compositions described above. Because the abundances of nearly all elements form distinct clusters, comparisons of the mean values do represent the contrasts in composition between the rock types sampled. The circles show changes in composition between the upper flows at Site 319 and the lower flows, the triangles changes between the lower flows and the Site 321 rocks. This plot of normalized data reveals important facts about the nature of the differences between these three groups. We can define a trend in composition also shown on the scatter plots, from the upper flows at Site 319, to the lower flows at 319 , to the rocks in 321 . Along this trend $\mathrm{Fe}, \mathrm{Ti}$, and the $\mathrm{REE}$ increase, while $\mathrm{Mg}, \mathrm{Cr}$, and $\mathrm{Cu}$ clearly decrease.

\section{DISCUSSION}

The compositional variations between these three rock types suggest the interesting possibility that the same petrochemical process produced the differences within the basalt flows in the 16 m.y. old crust at Site 319 (Hogan and Dymond, this volume) and between the older erupted rocks at this site and those from the much older crust (40 m.y.) at Site 321.

Fractional crystallization is often used to explain differences in trace element distribution patterns in volcanic rocks. Figure 9, derived from the Rayleigh model of fractional crystallization, can be used to illustrate this process. It shows clearly that, for elements rejected by solid phases, e.g., the heavy REE in olivine, orthopyroxene, plagioclase, and clinopyroxene, with partition coefficients $(K)$ less than 0.1 , nearly $50 \%$ of the liquid must crystallize in order to increase the abundance of these elements in the melt by a factor of $\sim 2$. Those elements strongly fractionated into solid phases, e.g., nickel into olivine, $K \cong 14$, or $\mathrm{Cr}$ into clinopyroxene, $K \cong 18$, are depleted by a factor of $\sim 2$ by approximately $5 \%$ crystallization. The heavy REE in 
TABLE 1

List of Samples

\begin{tabular}{|c|c|}
\hline $\begin{array}{l}\text { Sample } \\
\text { Code }\end{array}$ & $\begin{array}{l}\text { DSDP Sample } \\
\text { (Interval in } \mathrm{cm} \text { ) }\end{array}$ \\
\hline $319-1$ & $319-13-1,48-51$ \\
\hline $319-2$ & $319-13-1,117-125$ \\
\hline $319-3$ & $319-13-1,140-143$ \\
\hline $319 A-1$ & $319 \mathrm{~A}-1-1,138-142$ \\
\hline 319A-2 & $319 A-2-1,114-119$ \\
\hline $319 A-3$ & $319 A-2-1,144-148$ \\
\hline $319 A-4$ & $319 \mathrm{~A}-2-2,114-117$ \\
\hline $319 A-5$ & $319 \mathrm{~A}-3-1,73-78 / 98-100$ \\
\hline 319A-6 & $319 \mathrm{~A}-3-2,14-17$ \\
\hline 319A-7 & $319 A-3-2,127-130$ Unalt. \\
\hline $319 A-8$ & $319 \mathrm{~A}-3-2,127-130$ Altered \\
\hline 319A-9 & $319 A-3-3,46-49$ \\
\hline $319 A-10$ & $319 A-3-3,106-109$ \\
\hline $319 \mathrm{~A}-11$ & $319 A-3-4,18-21$ \\
\hline 319A-12 & $319 A-3-4,100-103$ \\
\hline $319 A-13$ & $319 A-3-5,37-41$ \\
\hline 319A-14 & $319 \mathrm{~A}-4-1,129-132$ \\
\hline $319 \mathrm{~A}-15$ & $319 \mathrm{~A}-5-1,76-79$ \\
\hline $319 A-16$ & $319 A-5-1,111-115$ \\
\hline 319A-17 & $319 A-6-1,84-89$ \\
\hline $319 A-18$ & 319 A-7-1, 105-109 \\
\hline $319 A-19$ & $319 \mathrm{~A}-7-1,119-122$ \\
\hline $320 \mathrm{~B}-1$ & $320 \mathrm{~B}-3-1,120-125$ \\
\hline $320 \mathrm{~B}-2$ & $320 \mathrm{~B}-4-1,130-133$ \\
\hline $320 \mathrm{~B}-3$ & $320 \mathrm{~B}-5-1,118-123$ \\
\hline $321-1$ & $321-13-4,119-124$ \\
\hline $321-2$ & $321-14-1,39-42$ \\
\hline $321-3$ & $321-14-1,45-47$ \\
\hline 3214 & $321-14-1,99-102$ \\
\hline $321-5$ & $321-14-1,124-126$ \\
\hline $321-6$ & $321-14-2,12-15$ \\
\hline $321-7$ & $321-14-2,127-130$ \\
\hline $321-8$ & $321-14-3,12-13$ \\
\hline $321-9$ & $321-14-3,92-100$ \\
\hline $321-10$ & $321-14-3,93-96$ \\
\hline $321-11$ & $321-14-4,20-23$ \\
\hline $321-12$ & $321-14-4,58-60$ \\
\hline $321-13$ & $321-14-4,61-64$ \\
\hline
\end{tabular}

Figure 8 show enrichment factors of about 1.5 or more which require $30 \%$ to $40 \%$ crystallization. On the other hand, $\mathrm{Ni}$ and $\mathrm{Cr}$ show relative depletions of less than $50 \%$, which means that no more than $5 \%$ crystallization of olivine and clinopyroxene could be proposed to account for the observed fractionations. The unavoidable conclusion is that fractional crystallization alone cannot account for the observed variations.

On the other hand, a partial melting model avoids some of these difficulties. Some preliminary results of such modeling are presented here. We assume that the various liquids are produced as separate partial melts, each under a specified set of conditions. That is, we specify the proportion of each solid phase and of the liquid in the system with which the liquid last equilibrated. The model is that of Gast (1968) and Shaw (1970). Partition coefficient data are that used in Corliss (1970), taken from Higuchi and Nagasawa (1969), Onuma et al. (1968), Wager and Mitchell (1951), Muir and Tilley (1964), DeVore (1955), Taylor et al. (1969), and Schnetzler and Philpotts (1970). Fe and Ti, both important to the discussion, are not included in this preliminary modeling. Figures 10 and 11 present normalization plots analogous to Figure 9 , relating the composition of liquids produced by equilibration with systems of different phase proportions but identical bulk compositions. Figure 10 shows the relationships between liquids produced by equilibrating in olivine (01) + orthopyroxene $(\mathrm{Opx})+$ clinopyroxene $(\mathrm{Cpx})+$ liquid systems having significant variations in Cpx content and small variations in the proportion of liquid.

As the Cpx content of the residual solid goes from 0 to $10 \%$, the $\mathrm{REE}$ and $\mathrm{Cr}$ are significantly fractionated, and, as in fractional crystallization, the relative depletion of $\mathrm{Cr}$ is not balanced by enrichment of the REE such that we can match the fractionations of the Leg 34 rocks in Figure 8.

Figure 11 shows the relationship between liquids produced in an $\mathrm{O} 1+\mathrm{Opx}+$ liquid system where the proportions of liquid varies significantly, balanced by changes in the proportion of Opx. Large variations in the abundances of elements can be produced in this way; the REE are enriched by a factor of $\sim 3$ in the liquid with only $10 \%$ melt.

The important point is, for those "incompatible," or large-ion lithophile (LIL) elements rejected by solid phases and strongly fractionated into the melt, their concentration in the melt is inversely proportional to the fraction of melt present in the system. In rocks undergoing partial melting, the fraction of liquid is small, therefore proportional changes in the fraction of liquid are large, producing significant relative changes in the concentration of LIL elements. During fractional crystallization, the fraction of liquid is large, and proportional changes in the fraction of liquid are small, so that large variations in the LIL elements cannot be produced in this way.

As for the Leg 34 rocks, it appears from modeling that some combination of the processes modeled in Figures 10 and 11 , that is, variations in both the proportions of phases and the extent of melting, must contribute to the observed patterns. In addition, it is likely that fractional crystallization and time variations in the bulk composition of the source material, both contribute, to some extent, to the observed contrasts in the element abundance patterns.

\section{REFERENCES}

Corliss, J.B., 1970. Mid-ocean ridge basalts: I. The origin of submarine hydrothermal solutions. II. Regional diversity along the Mid-Atlantic Ridge: Ph.D. Thesis, Scripps Institution of Oceanography.

DeVore, G., 1965. Crystal growth and the distribution of elements: J.Geol., v. 63, p. 471.

Gast, P.W., 1968. Trace element fractionation and the origin of tholeiitic and alkaline magmatypes: Geochim. Cosmochim. Acta, v. 32, p. 1057-1086.

Higuchi, H. and Nagasawa, H., 1969. Partition of trace elements between rock forming minerals and the host volcanic rocks: Earth Planet. Sci. Lett., v. 7, p. 281-287.

Muir, J.D. and Tilley, C.E., 1964. Basalts from the northern part of the rift zone of the Mid-Atlantic Ridge: J. Petrol., v. 5 , p. $409-434$

Onuma, N., Higuchi, H., Wakita, H., and Nagasawa, H., 1968. Trace element partition between two pyroxenes and the host lava: Earth Planet. Sci. Lett., v. 5, p. 47-51.

Schnetzler, C.C. and Philpotts, J.A., 1970. Partition coefficients of rare earth elements bewteen igneous matrix 
TABLE 2A

Elemental Abundance Data

\begin{tabular}{|c|c|c|c|c|c|c|c|c|c|c|}
\hline & $319-1$ & $319-2$ & $319-3$ & 319A-1 & $319 A-2$ & $319 A-3$ & $319 A-4$ & $319 A-5$ & $319 A-6$ & $319 A-7$ \\
\hline \multicolumn{11}{|c|}{ Major Elements (\%) } \\
\hline $\mathrm{SiO}_{2}$ & 49.65 & 50.69 & 50.25 & 50.69 & 49.13 & 49.37 & 49.50 & 50.44 & 50.16 & 50.39 \\
\hline $\mathrm{TiO}_{2}^{2}$ & 1.29 & 1.24 & 1.30 & 1.26 & 2.13 & 2.08 & 2.14 & 2.18 & 2.12 & 2.11 \\
\hline $\mathrm{Al}_{2} \mathrm{O}_{3}$ & 14.67 & 14.58 & 14.41 & 13.98 & 13.95 & 13.58 & 14.13 & 13.87 & 13.73 & 14.60 \\
\hline $\mathrm{FeO}^{\mathrm{a}^{\mathrm{J}}}$ & - & 9.83 & 8.71 & 8.23 & - & - & 10.31 & - & 10.37 & 9.80 \\
\hline $\mathrm{MgO}$ & 7.86 & 7.59 & 7.63 & 7.08 & 5.97 & 5.72 & 6.67 & 6.32 & 6.62 & 6.73 \\
\hline $\mathrm{CaO}$ & 12.31 & 12.34 & 12.72 & 11.75 & 11.29 & 10.54 & 10.95 & 10.88 & 12.65 & 11.23 \\
\hline $\mathrm{Na}_{2} \mathrm{O}$ & - & 2.47 & 2.52 & 2.57 & - & - & 2.79 & - & 2.80 & 5.15 \\
\hline $\mathrm{K}_{2} \mathrm{O}$ & 0.05 & 0.20 & 0.04 & 0.20 & 0.48 & 0.51 & 0.11 & 0.09 & 0.11 & 0.16 \\
\hline $\mathrm{H}_{2} \mathrm{O}+$ & 0.49 & 0.30 & 0.47 & 0.26 & 0.61 & 0.76 & 0.70 & 0.48 & 1.07 & 0.66 \\
\hline $\mathrm{H}_{2}^{2} \mathrm{O}-$ & 0.62 & 0.19 & 0.97 & 0.28 & 0.73 & 0.88 & 1.00 & 1.14 & 0.59 & 0.79 \\
\hline \multicolumn{11}{|c|}{ Trace Elements (PPM) } \\
\hline $\mathrm{Sc}$ & - & 42.90 & 42.70 & 40.30 & - & - & 43.30 & - & 43.40 & 43.10 \\
\hline $\mathrm{Cr}$ & - & 256.00 & 229.00 & 230.00 & - & - & 181.00 & - & 181.00 & 203.00 \\
\hline Co & - & 42.50 & 45.10 & 44.00 & - & - & 39.80 & - & 28.00 & 57.80 \\
\hline $\mathrm{Ni}$ & 73.10 & 65.00 & 71.60 & 83.00 & 57.00 & 54.10 & 66.30 & 62.30 & 64.00 & 122.50 \\
\hline $\mathrm{Cu}$ & 91.20 & 83.50 & 96.60 & 88.80 & 43.90 & 61.60 & 75.10 & 71.40 & 68.90 & 71.10 \\
\hline $\mathrm{La}$ & - & 2.22 & 2.10 & 2.13 & - & - & 3.72 & - & 4.19 & 6.96 \\
\hline $\mathrm{Ce}$ & - & 5.01 & 5.36 & 4.14 & - & - & - & - & - & 11.01 \\
\hline $\mathrm{Sm}$ & - & 2.82 & 2.76 & 2.94 & - & - & 4.56 & - & 4.48 & 8.12 \\
\hline $\mathrm{Eu}$ & - & 1.11 & 1.19 & 0.98 & - & - & 1.51 & - & 1.70 & 1.70 \\
\hline $\mathrm{Tb}$ & - & 0.62 & 0.69 & 0.64 & - & - & 0.82 & - & 0.86 & 1.04 \\
\hline $\mathrm{Yb}$ & - & 3.25 & 2.66 & 3.17 & - & - & - & - & - & 4.90 \\
\hline $\mathrm{Lu}$ & - & 0.51 & 0.51 & 0.43 & - & - & 0.60 & - & 0.60 & 0.69 \\
\hline $\mathrm{Hf}$ & - & 2.06 & 1.92 & 1.61 & - & - & 4.09 & - & 3.98 & 3.51 \\
\hline
\end{tabular}

${ }^{\mathrm{a}}$ Total iron as $\mathrm{FeO}$.

TABLE 2B

Elemental Abundance Data

\begin{tabular}{|c|c|c|c|c|c|c|c|c|c|c|}
\hline & 319A-8 & 319A-9 & $319 A-10$ & 319A-11 & 319A-12 & $319 \mathrm{~A}-13$ & 319A-14 & $319 A-15$ & $319 A-16$ & $319 A-17$ \\
\hline \multicolumn{11}{|c|}{ Major Elements (\%) } \\
\hline $\mathrm{SiO}_{2}$ & 49.15 & 49.43 & 49.90 & 50.65 & 50.89 & 50.10 & 50.33 & 49.80 & 50.89 & 50.39 \\
\hline $\mathrm{TiO}_{2}^{2}$ & 1.92 & 1.97 & 2.12 & 1.97 & 1.95 & 1.94 & 1.90 & 1.76 & 1.68 & 1.88 \\
\hline $\mathrm{Al}_{2} \mathrm{O}_{3}$ & 13.97 & 13.70 & 13.79 & 14.15 & 14.00 & 13.90 & 13.66 & 13.79 & 14.09 & 14.23 \\
\hline $\mathrm{FeO}^{\mathrm{a}}$ & - & 11.82 & 10.26 & 10.79 & 10.22 & 10.85 & 10.40 & 10.58 & - & 15.43 \\
\hline $\mathrm{MgO}$ & 6.12 & 5.80 & 6.96 & 6.69 & 7.13 & 7.47 & 7.56 & 7.11 & 6.96 & 5.63 \\
\hline $\mathrm{CaO}$ & 10.86 & 10.52 & 11.15 & 10.86 & 10.79 & 10.70 & 11.16 & 11.30 & 11.09 & 11.58 \\
\hline $\mathrm{Na}_{2} \mathrm{O}$ & - & 3.02 & 2.74 & 3.05 & 2.70 & 2.79 & 2.70 & 2.67 & - & 2.80 \\
\hline $\mathrm{K}_{2} \mathrm{O}$ & 0.42 & 0.74 & 0.11 & 0.11 & 0.11 & 0.11 & 0.10 & 0.14 & 0.08 & 0.57 \\
\hline $\mathrm{H}_{2} \mathrm{O}+$ & 1.14 & 0.82 & 0.63 & 0.51 & 0.57 & 0.58 & 0.55 & 0.53 & 0.68 & 0.69 \\
\hline $\mathrm{H}_{2}^{2} \mathrm{O}-$ & 0.90 & 0.54 & 1.16 & 0.45 & 0.85 & 0.85 & 1.21 & 0.54 & 1.28 & 0.61 \\
\hline \multicolumn{11}{|c|}{ Trace Elements (PPM) } \\
\hline $\mathrm{Sc}$ & - & 41.10 & 42.40 & 41.70 & 40.30 & 40.80 & 41.30 & 41.70 & - & 63.90 \\
\hline $\mathrm{Cr}$ & - & 192.00 & 190.00 & 196.00 & 169.00 & 179.00 & 175.00 & 217.00 & - & 335.00 \\
\hline Co & - & 40.80 & 43.60 & 44.00 & 39.40 & 44.30 & 41.20 & 42.60 & - & 68.30 \\
\hline $\mathrm{Ni}$ & 55.00 & 44.40 & 77.00 & 71.00 & 78.00 & 94.00 & 94.00 & 77.00 & 72.00 & 78.00 \\
\hline $\mathrm{Cu}$ & 63.50 & 48.00 & 66.10 & 66.20 & 64.00 & 65.90 & 69.90 & 71.60 & 75.30 & 61.70 \\
\hline $\mathrm{La}$ & - & 5.43 & 3.81 & 5.28 & 3.78 & 2.94 & 3.54 & 3.88 & - & 4.10 \\
\hline $\mathrm{Ce}$ & - & 11.10 & 11.05 & 10.90 & - & 10.93 & - & 8.87 & - & 14.70 \\
\hline $\mathrm{Sm}$ & - & 4.66 & 4.30 & 4.79 & 4.34 & 4.00 & 4.03 & 4.21 & - & 4.56 \\
\hline $\mathrm{Eu}$ & - & 1.63 & 1.71 & 1.72 & 1.59 & 1.62 & 1.55 & 1.71 & - & 2.53 \\
\hline $\mathrm{Tb}$ & - & 1.00 & 0.87 & 1.04 & 0.74 & 0.95 & 0.87 & 0.97 & - & 1.46 \\
\hline $\mathrm{Yb}$ & - & 4.41 & 5.28 & 5.30 & - & 3.68 & - & - & - & - \\
\hline $\mathrm{Lu}$ & - & 0.66 & 0.68 & 0.71 & 0.51 & 0.66 & 0.65 & 0.81 & - & 0.95 \\
\hline $\mathrm{Hf}$ & - & 3.42 & 3.47 & 3.63 & 3.76 & 3.48 & 3.72 & 3.04 & - & 4.74 \\
\hline
\end{tabular}

${ }^{\mathrm{a}}$ Total iron as FeO.

material and rockforming mineral phenocrysts-II: Geochim. Cosmochim. Acta, v. 34, p. 331-340.

Shaw, D.M., 1970, Trace element fractionation during anatexis: Geochim. Cosmochim. Acta, v. 34, p. 237-242.

Taylor, S.R., Kaye, M., White, A.J.R., Duncan, A.R., and Ewart, A., 1969. Genetic significance of $\mathrm{Co}, \mathrm{Cr}, \mathrm{Ni}, \mathrm{Sc}$ and
V content of andesites: Geochim. Cosmochim. Acta, v. 33, p. 275-286.

Wager, L.R. and Mitchell, R.L., 1951. The distribution of trace elements during strong fractionation of basic magma-a further study of the Skaergaard intrusion, East Greenland: Geochim. Cosmochim. Acta, v. 1, p. 129. 
TABLE 2C

Elemental Abundance Data

\begin{tabular}{|c|c|c|c|c|c|c|c|c|c|c|}
\hline & $319 \mathrm{~A}-18$ & $319 \mathrm{~A}-19$ & 320B-1 & $320 \mathrm{~B}-2$ & $320 \mathrm{~B}-3$ & $321-1$ & $321-2$ & $321 \cdot 3$ & $321-4$ & $321-5$ \\
\hline \multicolumn{11}{|c|}{ Major Elements (\%) } \\
\hline $\mathrm{SiO}_{2}$ & 49.84 & 50.54 & 48.83 & 49.86 & 51.53 & 47.61 & 50.87 & 50.03 & 50.16 & 49.58 \\
\hline $\mathrm{TiO}_{2}$ & 1.73 & 1.92 & 1.64 & 1.64 & 2.34 & 2.71 & 2.49 & 2.46 & 2.58 & 2.49 \\
\hline $\mathrm{Al}_{2} \mathrm{O}_{3}$ & 14.15 & 13.98 & 15.88 & 15.26 & 13.46 & 14.07 & 13.01 & 13.11 & 13.12 & 12.38 \\
\hline $\mathrm{FeO}^{\mathrm{a}}$ & - & 9.74 & 9.31 & 8.69 & 10.16 & 11.15 & - & - & 11.84 & - \\
\hline $\mathrm{MgO}$ & 7.02 & 7.19 & 5.09 & 6.02 & 6.06 & 5.60 & 6.16 & 6.08 & 5.90 & 5.91 \\
\hline $\mathrm{CaO}$ & 11.28 & 11.58 & 11.91 & 11.53 & 10.39 & 10.76 & 10.38 & 10.44 & 10.79 & 9.71 \\
\hline $\mathrm{Na}_{2} \mathrm{O}$ & - & 2.52 & 2.51 & 2.71 & 2.76 & 2.91 & - & - & 2.43 & - \\
\hline $\mathrm{K}_{2} \mathrm{O}$ & 0.15 & 0.15 & 0.32 & 0.25 & 0.33 & 0.35 & 0.11 & 0.16 & 0.26 & 0.77 \\
\hline $\mathrm{H}_{2} \mathrm{O}+$ & 0.86 & 0.71 & 1.08 & 0.94 & 0.64 & 0.79 & 0.31 & 0.34 & 0.63 & 0.99 \\
\hline $\mathrm{H}_{2}^{2} \mathrm{O}-$ & 1.17 & 1.17 & 1.76 & 1.83 & 0.53 & 1.32 & 0.54 & 0.43 & 1.20 & 1.38 \\
\hline \multicolumn{11}{|c|}{ Trace Elements (PPM) } \\
\hline $\mathrm{Sc}$ & - & 40.90 & 36.50 & 38.30 & 40.80 & 46.70 & - & - & 42.90 & - \\
\hline $\mathrm{Cr}$ & - & 109.80 & 255.00 & 282.00 & 104.00 & 123.20 & - & - & 103.30 & - \\
\hline Co & - & 39.60 & 35.90 & 39.60 & 34.90 & 41.70 & - & - & 42.00 & - \\
\hline $\mathrm{Ni}$ & 84.00 & 81.00 & 82.00 & 99.40 & 56.00 & 55.00 & 60.00 & 64.00 & 50.00 & 46.00 \\
\hline $\mathrm{Cu}$ & 69.50 & 69.10 & 77.70 & 75.70 & 63.00 & 77.10 & 61.40 & 59.60 & 57.00 & 59.30 \\
\hline $\mathrm{La}$ & - & 2.95 & 3.15 & 3.27 & 4.51 & 6.56 & - & - & 5.99 & - \\
\hline $\mathrm{Ce}$ & - & - & - & 8.72 & 12.10 & 16.70 & - & - & - & - \\
\hline $\mathrm{Sm}$ & - & 3.74 & 3.14 & 3.37 & 5.38 & 7.08 & - & - & 5.15 & - \\
\hline $\mathrm{Eu}$ & - & 1.46 & 1.15 & 1.42 & 1.79 & 2.19 & - & - & 1.73 & - \\
\hline $\mathrm{Tb}$ & - & 0.66 & 0.55 & 0.71 & 1.15 & 1.41 & - & - & 1.06 & - \\
\hline $\mathrm{Yb}$ & - & - & - & 4.41 & 6.10 & 6.75 & - & - & - & - \\
\hline $\mathrm{Lu}$ & - & 0.50 & 0.41 & 0.54 & 0.87 & 1.02 & - & - & 0.73 & - \\
\hline Hf & - & 3.45 & 3.00 & 2.75 & 3.82 & 4.77 & - & - & 4.43 & - \\
\hline
\end{tabular}

${ }^{\mathrm{a}}$ Total iron as $\mathrm{FeO}$.

TABLE 2D

Elemental Abundance Data

\begin{tabular}{|c|c|c|c|c|c|c|c|c|}
\hline & $321-6$ & $321-7$ & $321-8$ & $321-9$ & $321-10$ & $321-11$ & $321-12$ & $321-13$ \\
\hline \multicolumn{9}{|c|}{ Major Elements (\%) } \\
\hline $\mathrm{SiO}_{2}$ & 48.90 & 51.66 & 44.00 & 42.35 & 49.41 & 49.84 & 50.93 & 49.41 \\
\hline $\mathrm{TiO}_{2}^{2}$ & 2.61 & 2.59 & 2.13 & 1.90 & 2.48 & 2.52 & 2.63 & 2.46 \\
\hline $\mathrm{Al}_{2} \mathrm{O}_{3}$ & 12.64 & 13.20 & 10.92 & 9.57 & 13.02 & 12.75 & 12.92 & 12.57 \\
\hline $\mathrm{FeO}^{\mathrm{a}^{2}}$ & 12.32 & 12.95 & 13.72 & - & 12.35 & 13.12 & - & 12.37 \\
\hline $\mathrm{MgO}$ & 5.99 & 6.26 & 6.59 & 15.57 & 6.00 & 5.38 & 6.15 & 5.94 \\
\hline $\mathrm{CaO}$ & 11.10 & 9.66 & 11.49 & 2.01 & 10.60 & 8.92 & 9.23 & 9.45 \\
\hline $\mathrm{Na}_{2} \mathrm{O}$ & 3.68 & 2.66 & 2.09 & - & 2.56 & 2.70 & - & 2.37 \\
\hline $\mathrm{K}_{2} \mathrm{O}$ & 0.13 & 0.16 & 0.73 & 0.47 & 0.16 & 0.14 & 0.14 & 0.14 \\
\hline $\mathrm{H}_{2}^{2} \mathrm{O}+$ & 0.43 & 0.62 & 1.46 & 5.93 & 0.48 & 0.52 & 0.56 & 0.48 \\
\hline $\mathrm{H}_{2}^{2} \mathrm{O}-$ & 0.95 & 0.77 & 1.68 & 8.06 & 1.19 & 0.60 & 1.09 & 1.14 \\
\hline \multicolumn{9}{|c|}{ Trace Elements (PPM) } \\
\hline Sc & 41.90 & 43.80 & 36.90 & - & 43.30 & 42.80 & - & 40.80 \\
\hline $\mathrm{Cr}$ & 104.60 & 108.70 & 95.50 & - & 109.00 & 111.00 & - & 96.10 \\
\hline Co & 44.20 & 46.30 & 33.20 & - & 44.20 & 45.20 & - & 41.80 \\
\hline $\mathrm{Ni}$ & 44.00 & 53.00 & 45.00 & 50.00 & 110.00 & 45.50 & 50.30 & 44.50 \\
\hline $\mathrm{Cu}$ & 55.50 & 61.20 & 38.10 & 2.41 & 59.70 & 58.00 & 58.80 & 56.20 \\
\hline $\mathrm{La}$ & 5.82 & 6.34 & 7.54 & - & 6.02 & 5.72 & - & 5.70 \\
\hline $\mathrm{Ce}$ & 14.90 & 15.80 & 18.60 & - & 16.20 & 14.20 & - & 16.10 \\
\hline $\mathrm{Sm}$ & 5.96 & 5.70 & 5.72 & - & 5.38 & 5.93 & - & 4.96 \\
\hline Eu & 1.88 & 2.13 & 1.79 & - & 2.06 & 1.97 & - & 1.78 \\
\hline $\mathrm{Tb}$ & 1.24 & 1.38 & 1.45 & - & 1.23 & 1.31 & - & 1.07 \\
\hline $\mathrm{Yb}$ & 6.87 & 6.14 & 9.50 & - & 6.30 & 6.80 & - & 5.20 \\
\hline $\mathrm{Lu}$ & 0.90 & 0.90 & 1.28 & - & 0.94 & 0.94 & - & 0.81 \\
\hline $\mathrm{Hf}$ & 4.12 & 4.45 & 3.48 & - & 4.73 & 4.47 & - & 4.62 \\
\hline
\end{tabular}

${ }^{\mathrm{a}}$ Total iron as FeO. 

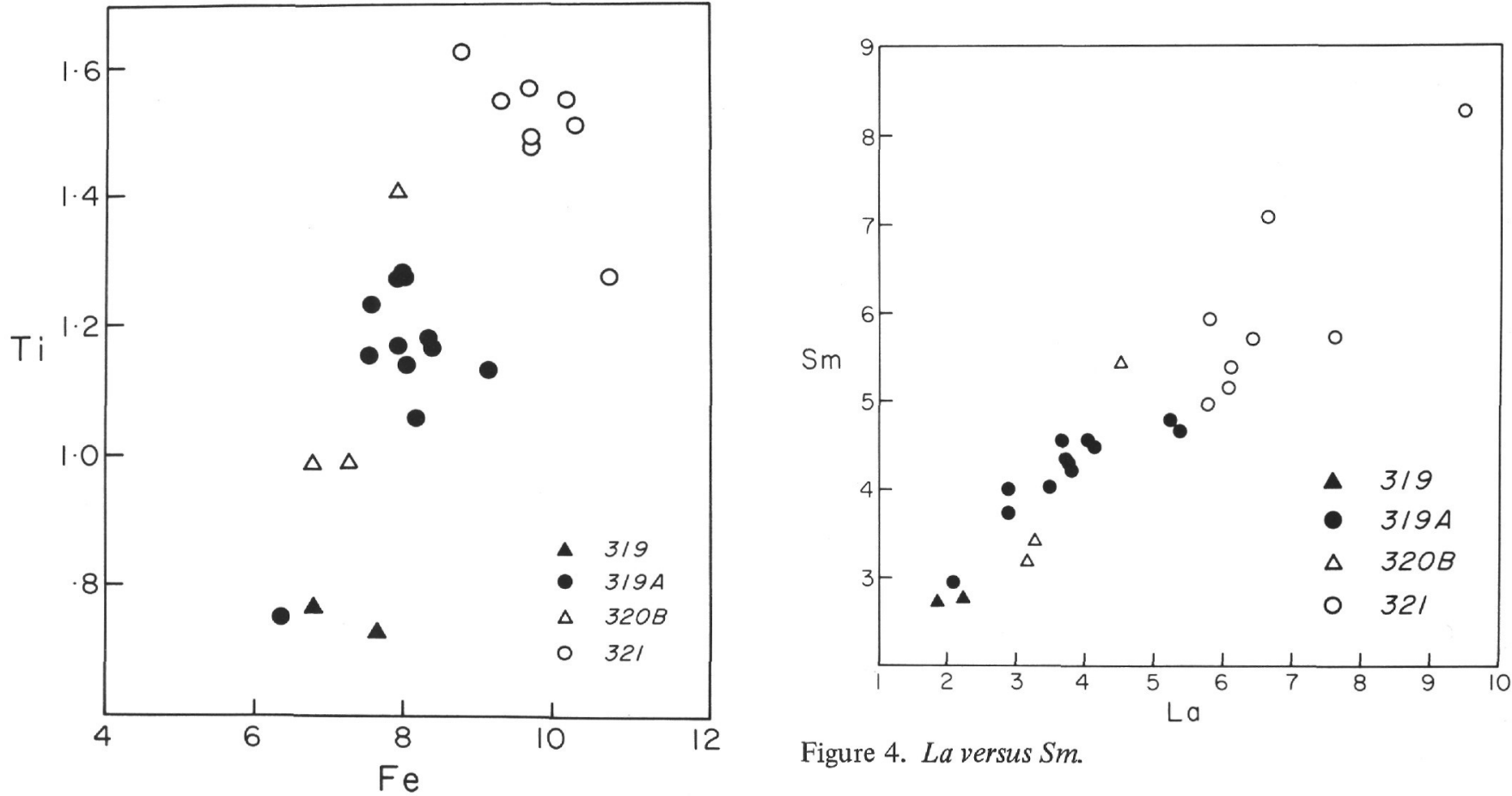

Figure 4. La versus Sm.

Figure 2. Fe versus Ti.
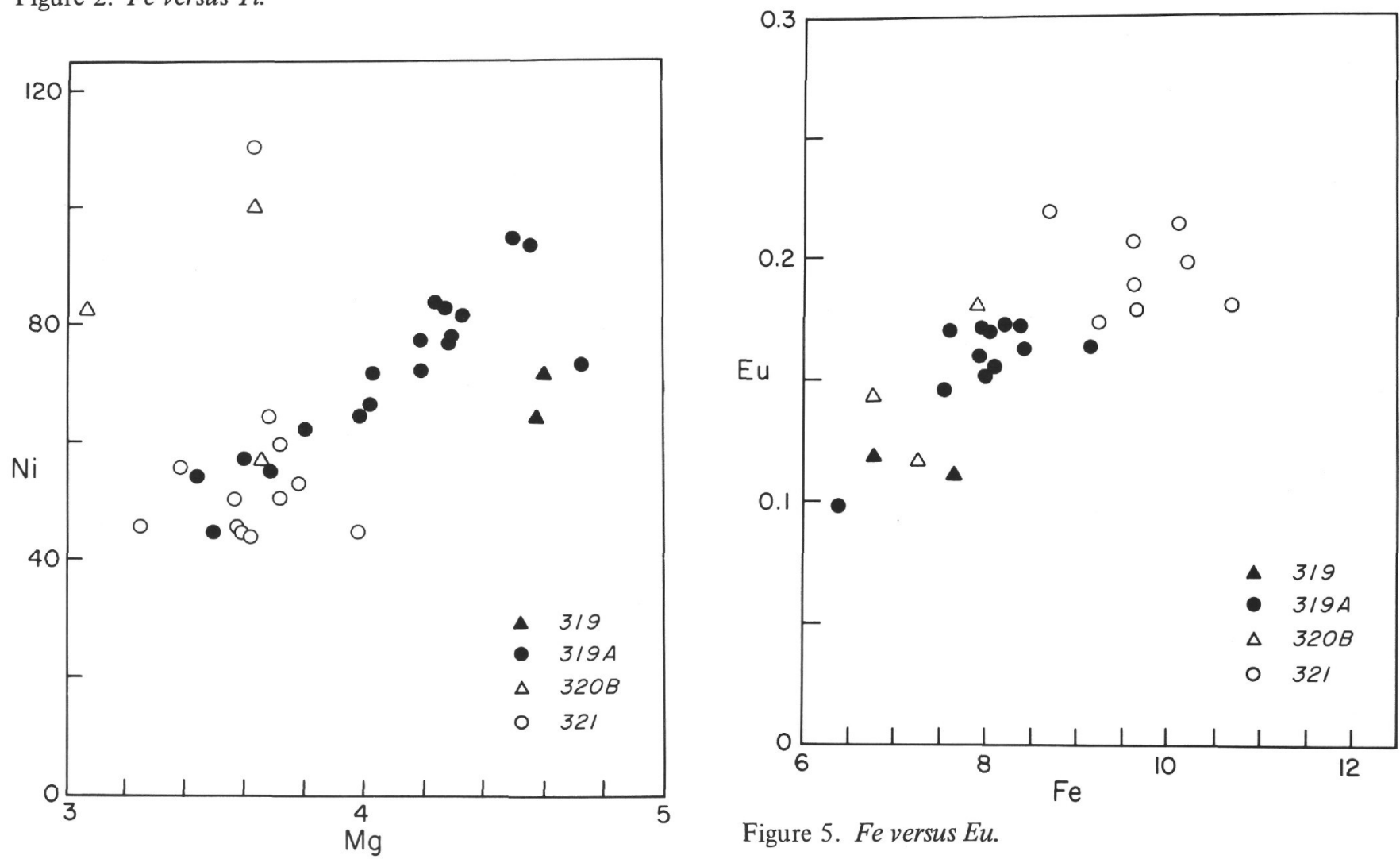

Figure 5. Fe versus Eu.

Figure 3. $M g$ versus $N i$. 


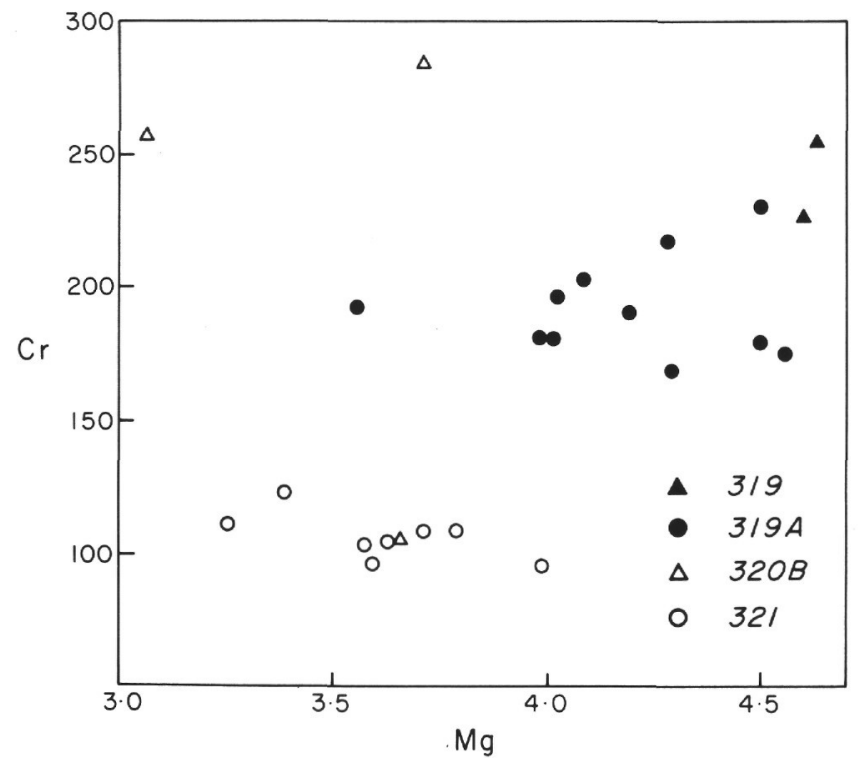

Figure 6. $\mathrm{Mg}$ versus $\mathrm{Cr}$.

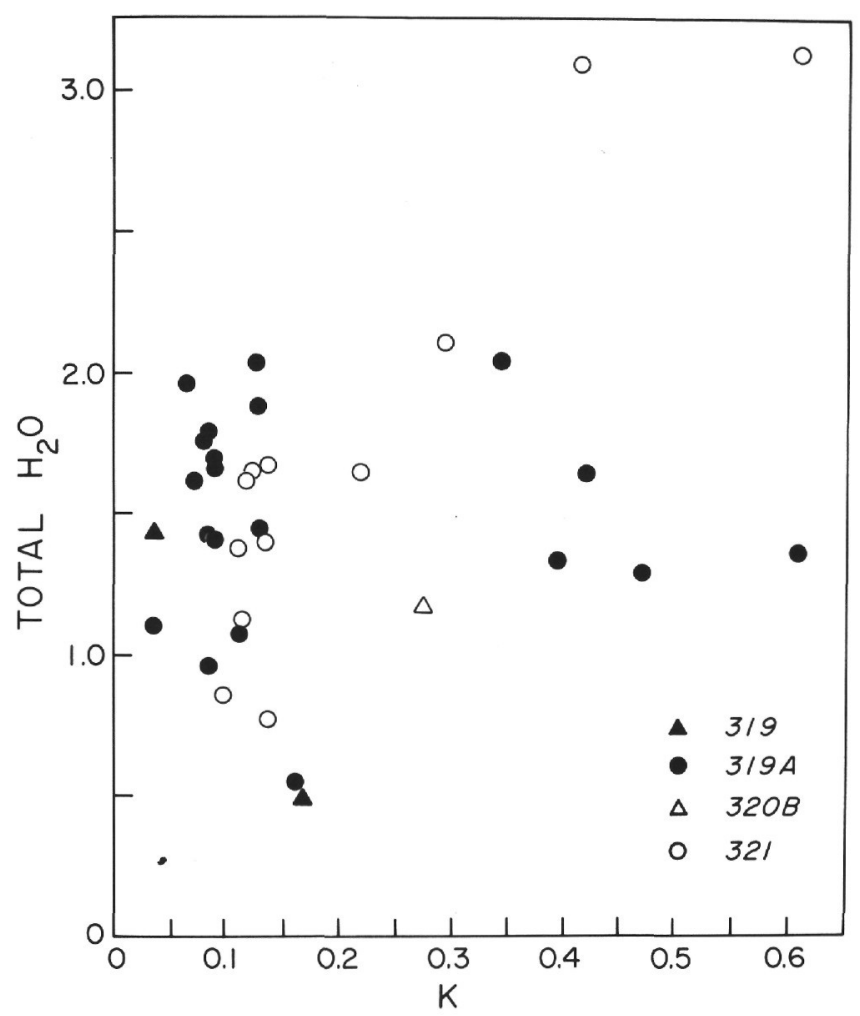

Figure 7. $\mathrm{K}$ versus total $\mathrm{H}_{2} \mathrm{O}$.

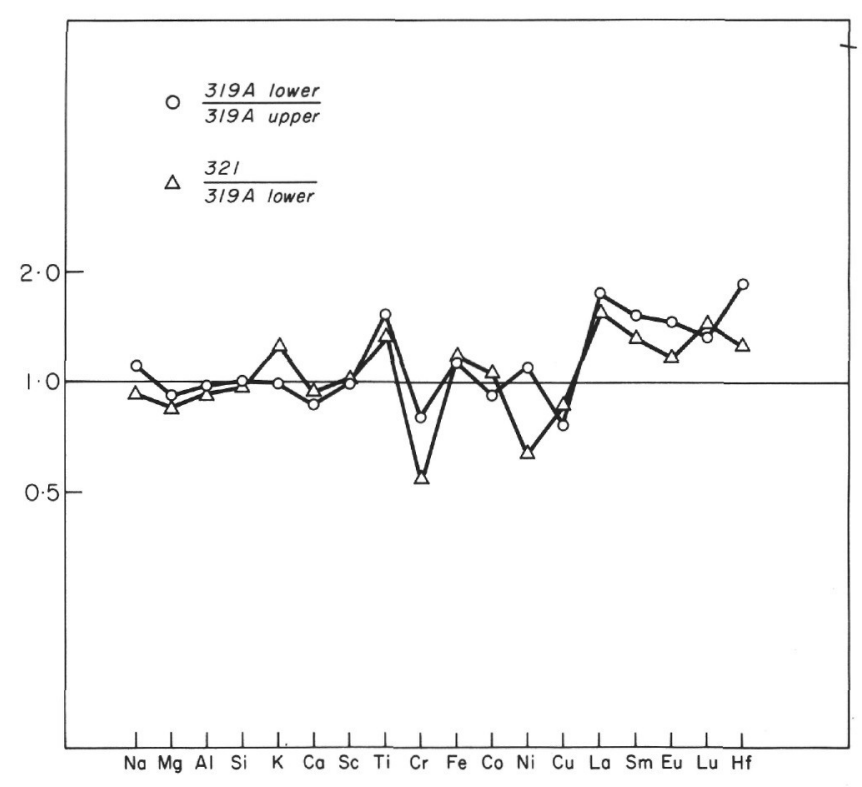

Figure 8. Normalization plots of mean abundances of three compositional clusters. Each line represents relative differences in composition between two rock groups.

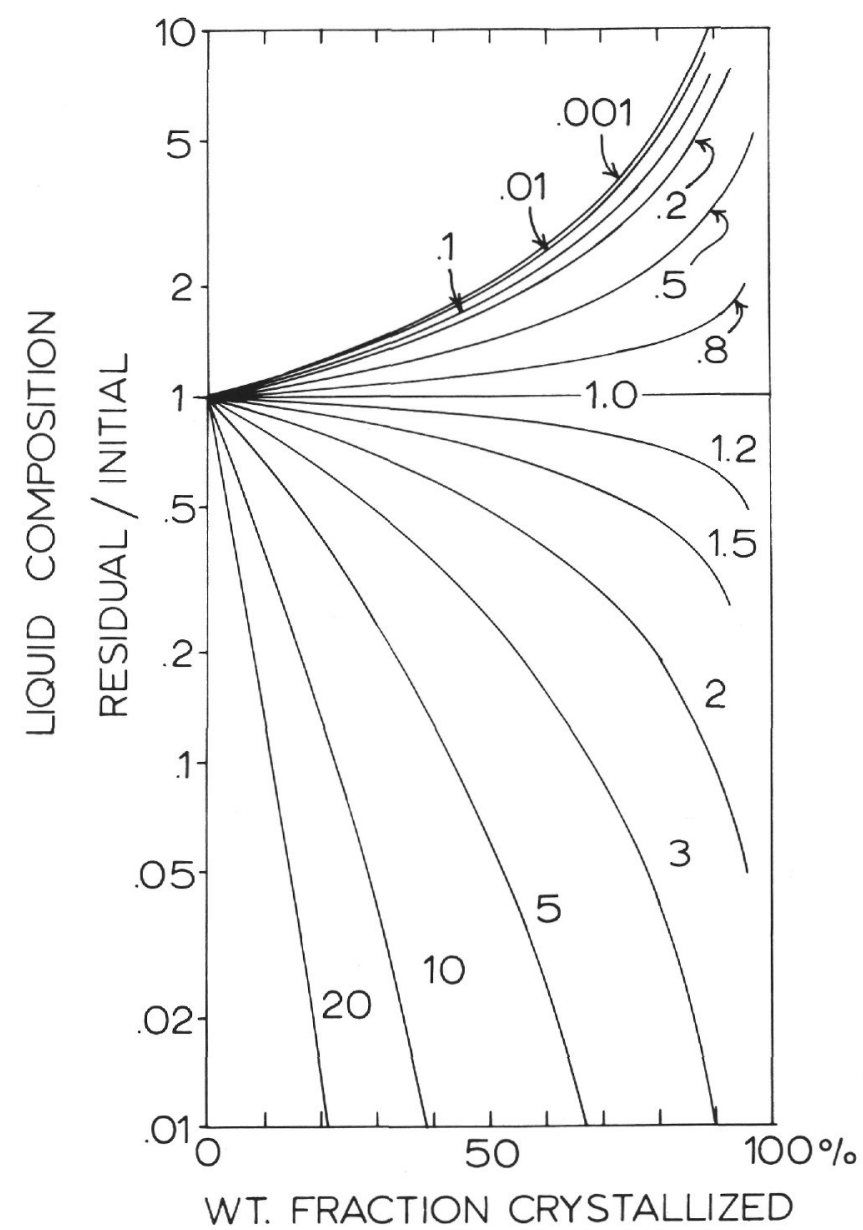

Figure 9. Effect of fractional crystallization on the composition of the residual liquid. Each curve shows, for the given partition coefficient, the depletion or enrichment of an element in the residual liquid as crystallization proceeds. 


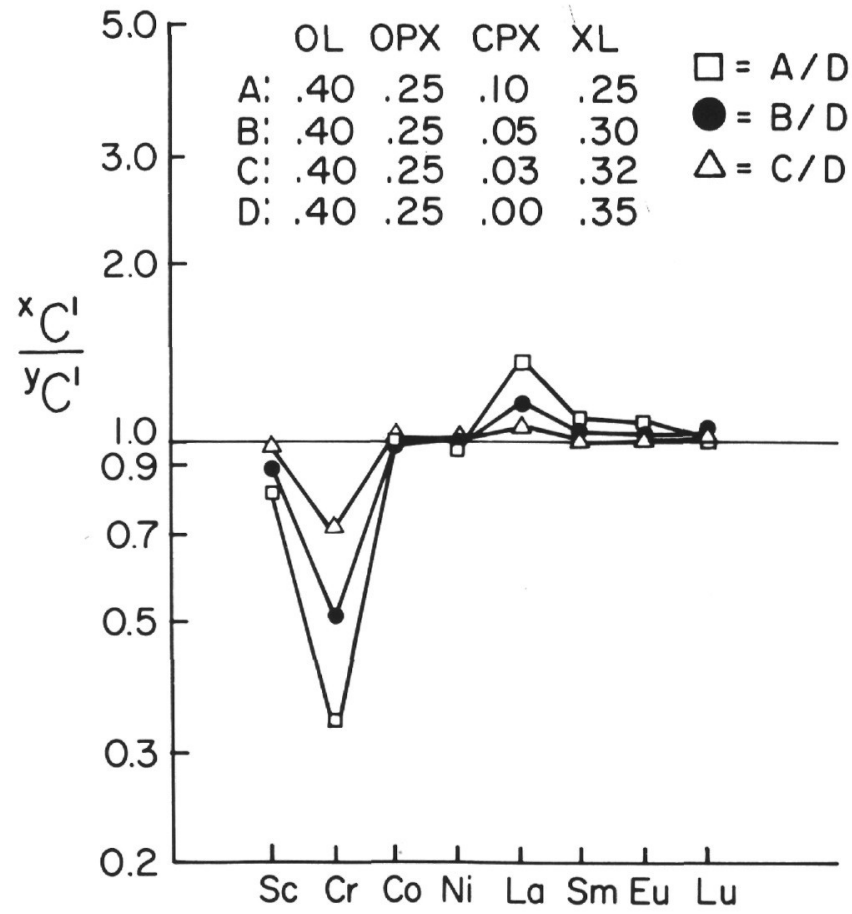

Figure 10. Partial melting model in $\mathrm{Ol}+\mathrm{Opx}+\mathrm{Cpx}+$ liquid $(X L)$ system. Lines represent relative differences in composition of liquids equilibrated in systems with varying amounts of Cpx and liquid.

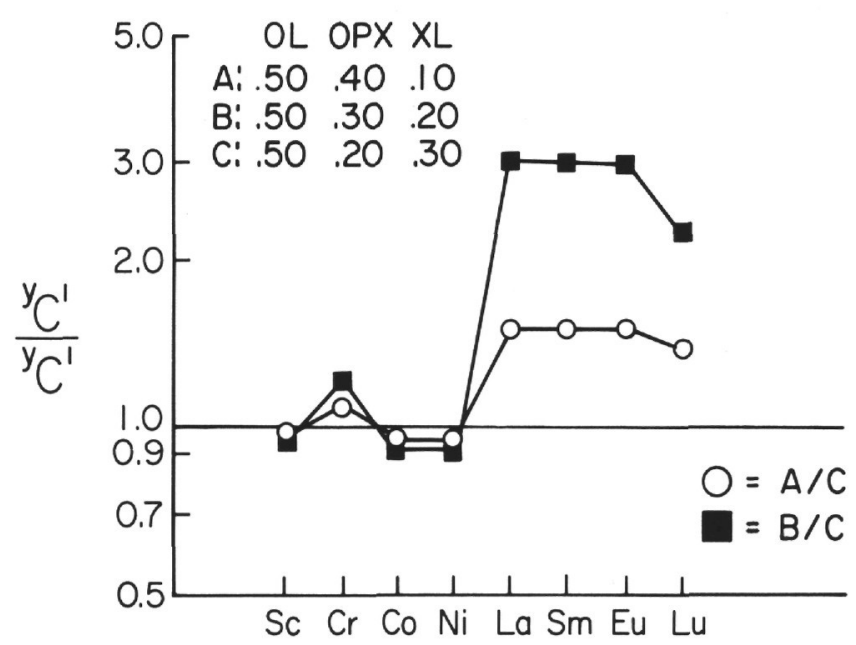

Figure 11. Partial melting model in $\mathrm{Ol}+\mathrm{Opx}+$ liquid $(X L)$ system. Lines represent relative differences in composition of liquids equilibrated in systems with varying amounts of Opx and liquid. 